\title{
Resistance of developing honeybee larvae during chronic exposure to dietary nicotine
}

\author{
H. Human ${ }^{\mathrm{a}}$, C.R. Archer ${ }^{\mathrm{a}}$, E.E. du Rand ${ }^{\mathrm{b}}$, C.W.W. Pirk ${ }^{\mathrm{a}}$ and S.W. Nicolson ${ }^{\mathrm{a} *}$ \\ ${ }^{a}$ Department of Zoology and Entomology, University of Pretoria, Pretoria 0002, South Africa \\ ${ }^{\mathrm{b}}$ Department of Biochemistry, University of Pretoria, Pretoria 0002, South Africa \\ *Corresponding author. \\ E-mail address: swnicolson@zoology.up.ac.za
}

\begin{abstract}
The effects of pesticides on honeybee larvae are less understood than for adult bees, even though larvae are chronically exposed to pesticide residues that accumulate in comb and food stores in the hive. We investigated how exposure to a plant alkaloid, nicotine, affects survival, growth and body composition of honeybee larvae. Larvae of Apis mellifera scutellata were reared in vitro and fed throughout development on standard diets with nicotine included at concentrations from 0 to $1000 \mu \mathrm{g} / 100 \mathrm{~g}$ diet. Overall mortality across all nicotine treatments was low, averaging $9.8 \%$ at the prepupal stage and $18.1 \%$ at the whiteeyed pupal stage, but survival was significantly reduced by nicotine. The mass of prepupae and white-eyed pupae was not affected by nicotine. In terms of body composition, nicotine affected water content but did not influence either protein or lipid stores of white-eyed pupae. We attribute the absence of consistent negative effects of dietary nicotine to detoxification mechanisms in developing honeybees, which enable them to resist both natural and synthetic xenobiotics.
\end{abstract}

Keywords: Apis mellifera scutellata; body composition; in vitro rearing; larval development; lipids; pesticides; protein 


\section{Introduction}

No single causative factor has been identified as responsible for global declines in honeybee (Apis mellifera L.) populations (Potts et al., 2010; vanEngelsdorp and Meixner, 2010; Vanbergen et al., 2013). However, there is general agreement that pesticides, whether acting alone or in combination with other stressors, are major threats to pollinators. These include pesticides of environmental origin, encountered by honeybees foraging for nectar, pollen and water, and also miticides used by beekeepers in the control of the Varroa destructor mite (Mullin et al., 2010) and small hive beetle Aethina tumida (Kanga and Somorin, 2011). They may result in direct poisoning (e.g. Suchail et al., 2000) or subtle sublethal effects. For example, sublethal neonicotinoid exposure can impair learning and memory in honeybee foragers (Williamson and Wright, 2013), and combined pesticide exposure reduces the foraging performance and colony growth of bumblebees (Gill et al., 2012). Pesticide exposure can increase vulnerability to a range of other stressors: for example, laboratory studies have shown increased worker bee mortality and energetic stress due to interactions between Nosema ceranae infection and sublethal doses of pesticides (Alaux et al., 2010a; Vidau et al., 2011). At the colony level, previous exposure to sublethal doses of neonicotinoid led to higher infection levels after challenge with N. ceranae (Pettis et al. 2012).

Compared to adult bees, relatively little work has examined the effects of pesticides on bee larvae; see review for neonicotinoids by Blacquière et al. (2012). However, high levels of agrochemical and miticide residues, including neonicotinoids, have been measured in pollen loads, bee bread, honey and propolis, as well as in the wax cells in which larvae develop and pollen is stored (Chauzat and Faucon, 2007; Chauzat et al., 2006; Mullin et al., 2010; Pettis et al., 2013; Wu et al., 2011). Wax may be a sink for hydrophobic chemicals (Chauzat and Faucon, 2007), which facilitates the transfer of pesticides from contaminated to uncontaminated comb (Wu et al., 2011). Larvae, far from being protected from pesticides in the colony, may thus be chronically exposed to an accumulation of chemical residues with potential additive or synergistic effects. There is evidence for delayed development of larvae reared in comb containing pesticide residues (Wu et al., 2011), and dose-dependent effects on rates of capping, pupation and eclosion were recorded by Yang et al. (2012) when they added imidacloprid solutions directly to cells in the hive containing newly emerged larvae. Interestingly, sublethal doses of imidacloprid used in this study did not affect larvae but did impair learning and memory in the resulting adult bees. In more controlled studies using in 
vitro rearing of larval honeybees, adverse effects of pesticides often manifest as reduced survival and body mass (Aupinel et al., 2007; Davis et al., 1988; Hendriksma et al., 2011; Zhu et al., 2014). The latter may be due to reduced nutrient assimilation (Bentz and Barbosa, 1990); alternatively, detoxification may be energetically costly, using resources that could otherwise be diverted to growth and development. Tolerance of dietary toxins is most likely due to the presence of metabolic detoxification mechanisms mediated in part by P450 enzymes (Johnson et al., 2012; Mao et al., 2011).

The systemic neonicotinoids, which have been detected as residues in nectar and pollen, have been blamed for colony losses and shown to affect bees negatively at both individual and colony levels (Blacquière et al., 2012; Decourtye and Devilliers, 2009). Until the development of this class of synthetic insecticides, the chemically related alkaloid nicotine was widely used as an insecticide, and still plays a role in organic farming (Casanova et al., 2002). Both nicotinoids and the related neonicotinoids target nicotinic acetylcholine receptors, but neonicotinoids have the advantage of selective toxicity for insects over vertebrates (Matsuda et al., 2001). Previously, we have found that survival of caged Apis mellifera scutellata workers was unaffected by $30 \mu \mathrm{M}(5 \mathrm{ppm})$ nicotine in sucrose diets, and actually improved in the case of weak colonies (Köhler et al., 2012a). At the colony level, Singaravelan et al. (2006) fed honeybees nicotine in sucrose solutions for 26 days: hatching success and larval survival were not affected by nicotine levels up to $30 \mu \mathrm{M}$, which can occur naturally in floral nectar of Nicotiana species (Adler et al., 2012).

Here we investigate the effect of dietary nicotine on the survival and development of $A . m$. scutellata larvae. Because nicotine may affect larval development, either directly through nutrient assimilation or indirectly through the costs of detoxification, we predicted that (1) nicotine will reduce survival, slow down development time and reduce prepupal mass; and (2) that nicotine will affect nutritional state, indicated by lipid and protein content at the white-eyed pupal stage. 


\section{Materials and Methods}

\subsection{Larval rearing}

Frames of A. m. scutellata were collected from colonies housed at the experimental farm of the University of Pretoria, South Africa ( $25^{\circ} 45^{\prime} 11^{\prime \prime} \mathrm{S}, 28^{\circ} 15^{\prime} 29^{\prime}$ 'E). Two day old worker honeybee larvae were grafted onto larval food in 48-well microtiter plates (Thermo Fisher Scientific, Rochester, New York), using a protocol slightly modified from Aupinel et al. (2005); see also Crailsheim et al. (2013). The grafted larvae were kept in an incubator (Memmert HCP 108, GmbH + Co. KG, Schwabach, Germany) under constant darkness at $34^{\circ} \mathrm{C}$ and $95 \%$ relative humidity (days 1 to 6 ). At the prepupal and pupal stages relative humidity was decreased to $80 \%$ and $70 \%$ respectively. Excluding eight larvae that died after initial grafting, an experiment consisted of five treatments: one control $(n=56$ larvae per plate) and four nicotine concentrations $(n=48)$. For each replicate a different colony $(n=5)$ was used, giving a total of 1240 larvae.

\subsection{Larval diets}

Three standard diets (A, B and C) were used for the in vitro rearing of larvae. All diets contained 50\% (w/w) fresh royal jelly (Stakich Inc., USA), glucose and fructose $(6 \%, 7.5 \%$ and $9 \%$ of each in diets $\mathrm{A}, \mathrm{B}$ and $\mathrm{C})$, and yeast extract $(1 \%, 1.5 \%$ and $2 \%$ in diets $\mathrm{A}, \mathrm{B}$ and C). The four treatment diets were prepared by adding nicotine $(1.01 \mathrm{mg} / \mu 1, \mathrm{~N} 3876$, Sigma Aldrich, Germany) to standard diets (A, B and C) at concentrations of 10, 50, 500 and 1000 $\mu \mathrm{g} / 100 \mathrm{~g}$ diet. All larvae received the standard larval diet (A) without nicotine for the first 24 $\mathrm{h}$ after grafting and were thereafter fed on a daily basis with fixed amounts of pre-warmed control or nicotine-containing diets; diet A on day 1 and 2 (10 $\mu 1$ per larva), diet B on day 3 $(20 \mu \mathrm{l})$ and diet $\mathrm{C}$ on days 4-6 (30, 40 and $50 \mu \mathrm{l}$ respectively).

\subsection{Survival, development and body mass}

Larvae were removed from the incubator on a daily basis, examined under a stereo microscope and mortality assessed. Dead larvae were removed from the wells and surviving larvae received fresh food. After defaecation, observed as yellow excretions, larvae were transferred into clean pupation plates. Development of larvae was recorded until they reached 
the white-eyed pupal stage. Randomly selected prepupal stage larvae ( $\mathrm{n}=10$ per plate) were carefully weighed to $0.1 \mathrm{mg}$ (Mettler Toledo MS204S, Switzerland) before the transfer to pupal plates and weighed again at the white-eyed pupal stage.

\subsection{Body composition: water, lipid and protein}

White-eyed pupae were sampled and killed by freezing at $-80^{\circ} \mathrm{C}$ for determination of body water and lipid content, and for protein analyses $(n=6$ each).

Water and lipid contents were analysed using gravimetric methods. White-eyed pupae were weighed to measure fresh mass, pricked four times with a sterile pin and then dried in glass vials at $60^{\circ} \mathrm{C}$. When pupae had reached a constant mass, $1 \mathrm{ml}$ of Folch's reagent (chloroform: methanol 2:1 v/v) was added to each vial using a glass pipette. After $24 \mathrm{~h}$ this solvent was removed using a 15 gauge needle and then replaced. After three washes with solvent, the remaining Folch's reagent was allowed to evaporate in a fume hood for $24 \mathrm{~h}$ before samples were returned to the drying oven. After $72 \mathrm{~h}$, these white-eyed-pupae were reweighed to give lipid-free dry mass. The water in each sample was calculated by subtracting the dry mass from the fresh mass of each sample, while the lipid content is the difference between the initial and final dry mass.

For soluble protein determinations, frozen white-eyed pupae were washed with ice cold, double distilled water to remove diet contamination before freeze drying for three days. Pupae were subsequently manually homogenised with a glass rod in $200 \mu 1$ of lysis buffer, consisting of $40 \mathrm{mM}$ Tris, $7 \mathrm{M}$ urea, $2 \%$ (v/v) Triton X-100 and Complete Protease Inhibitor Cocktail tablets (Roche Diagnostics, Mannheim, Germany). These samples were then sonified for $30 \mathrm{~min}$ and centrifuged for $10 \mathrm{~min}$ at $13000 \mathrm{x}$ g. The supernatant was collected and diluted 100 fold in a Tris-based buffer, and total protein content was determined by the Bradford assay (Bradford, 1976) using serial dilutions of bovine serum albumin standard (Sigma-Aldrich, Germany) to establish a standard curve. Absorbance was measured at 595 nm using a BioTek Eon microplate reader (Analytical and Diagnostic Products, Johannesburg, South Africa). 


\subsection{Statistics}

Mortality of prepupae and the proportion of larvae reaching the white-eyed stage by day 9 were compared using $\mathrm{Chi}^{2}$ tests. Body mass was compared using Kruskal-Wallis ANOVA and a multiple comparison of mean ranks for all groups, with nicotine concentration as the grouping variable. Non-parametric statistics were performed since the dependent variable violated the assumptions, normal distribution and homogeneity of variance for parametric test statistics (Pirk et al., 2013). For water, protein and lipid contents of white-eyed pupae, Kruskal-Wallis ANOVAs with multiple comparison of mean ranks for all groups were conducted with nicotine concentration as the grouping, the percentages of water, protein and lipid as dependent variables. Since the variable mass did not violate any assumptions for parametric statistics, mass was compared using parametric ANOVA with nicotine concentration as the independent variable. Significance level was $P \leq 0.05$; data are presented as means $\pm \mathrm{SD}$.

\section{Results}

\subsection{Survival and body mass}

Development time was not significantly affected by nicotine $\left(\chi^{2}=1.65, \mathrm{df}=4\right)$, although the number of larvae reaching the white-eyed pupal stage $(n=1016)$ at day 9 ranged between $36 \%-47 \%$, with the highest nicotine concentration giving the lowest percentage. The overall observed mortality (out of 1240) was low: $9.8 \%$ at the prepupal stage and $18.1 \%$ at the white-eyed pupal stage.

For white-eyed pupae the $\mathrm{Chi}^{2}$ test to evaluate differences in mortality was significant $\left(\chi^{2}=\right.$ 9.97, df = 4, $P<0.041 ; \mathrm{n}=5 \times 248$ larvae; Fig. 1). The highest mortality of white-eyed pupae was found for the two highest nicotine concentrations. There were no significant effects of nicotine on the mass of prepupae $\left(\mathrm{F}_{4,245}=0.71, P<0.59\right)$ or white-eyed pupae $\left(\mathrm{F}_{4,180}=0.45\right.$, $P<0.77$ ) (Fig. 2).

\subsection{Body composition: water, lipid and protein}

Water, lipid and protein contents of the white-eyed pupae are shown in Fig. 3. Nicotine had no effect on either lipid as a percentage of dry mass $\left(\mathrm{H}_{4,149}=2.99, P<0.56\right)$ or protein as a 


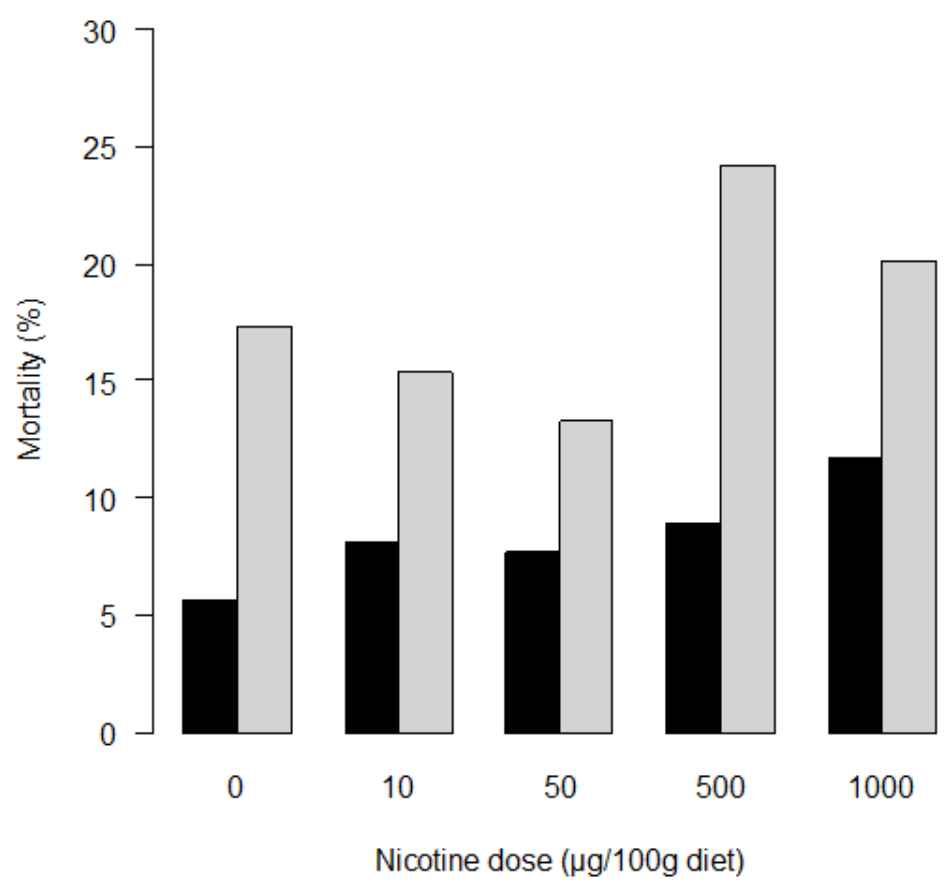

Fig. 1. Effect of nicotine concentration on the mortality (\% of larvae that survived initial grafting) of prepupae (black bars) and white-eyed pupae (grey bars For white eyed pupae, mortality was significantly affected by nicotine concentration.



Fig. 2. Effect of nicotine concentration on body mass (mg) of prepupae (black bars) and white-eyed pupae (grey bars). Data are presented as means \pm SD. Body mass of both prepupae and white-eyed pupae was unaffected by nicotine. 


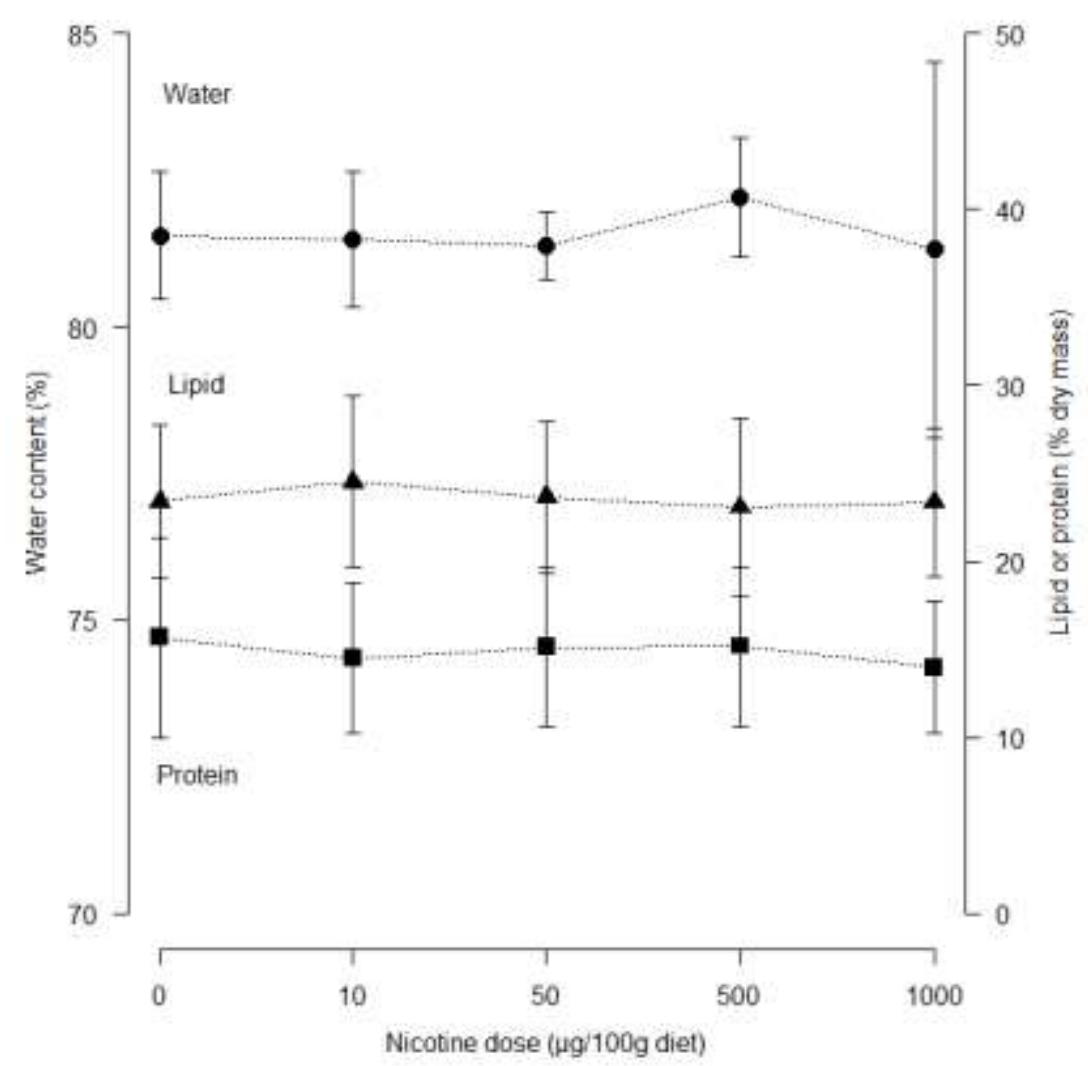

Fig. 3. Effect of nicotine concentration on body composition of white-eyed pupae: water content (\% wet mass,

$\bullet$ ), protein content ( $\%$ dry mass, $\boldsymbol{\Delta}$ ) and lipid content (\% dry mass, $\mathbf{a})$. Data are presented as means \pm SD. Lipid and protein contents were unaffected by nicotine. However, water content was significantly lower on $50 \mu \mathrm{g} / 100$ $\mathrm{g}$ nicotine than on a concentration of $500 \mu \mathrm{g} / 100 \mathrm{~g}$.

percentage of dry mass $\left(\mathrm{H}_{4,149}=0.86, P<0.94\right)$; however, it had an significant effect on the water content of pupae $\left(\mathrm{H}_{4,149}=10.95, P<0.03\right)$ with a nicotine concentration of $50 \mu \mathrm{g} / 100 \mathrm{~g}$ resulting in a significantly lower water content than a concentration of $500 \mu \mathrm{g} / 100 \mathrm{~g}(Z=$ $3.09, P<0.02)$.

\section{Discussion}

Although we are beginning to understand how pesticides interact with a range of other environmental stressors in adult honeybee workers to drive population declines, our understanding of larval responses to pesticide exposure is comparatively poor. Given that larval health is vital to colony survival in honeybees, we must improve our understanding of how larvae respond to pesticide exposure. Here, we find that larvae of $A$. $m$. scutellata were 
remarkably unaffected by the inclusion of nicotine in their diet, even at fairly high concentrations. Although survival was reduced in white-eyed pupae fed high doses of nicotine, pupae were able to tolerate lower doses without experiencing elevated mortality. Nevertheless, water content of the larvae was significantly affected by nicotine concentration. In the absence of a clear trend (Fig. 3), we could speculate that the effect is caused by detoxification processes involving the $\mathrm{P} 450$ cycle resulting in production of metabolic water. Additionally, despite possible metabolic costs of detoxification, nicotine did not have deleterious effects on development time, growth or body composition. Here we discuss the potential mechanisms that may underpin this resistance to nicotine.

Nicotine can be present in both pollen and nectar of Nicotiana species (Detzel and Wink, 1993; Adler et al., 2012) but bees are more likely to be exposed through its continuing use as a botanical insecticide (Casanova et al., 2002). The lack of consistent, negative effects of nicotine on the survival of developing honeybee larvae supports previous studies showing limited effects of nicotine in sucrose solutions on survival of caged workers (Köhler et al., 2012a) and on hatching success and survival of honeybee larvae in 'minihives' maintained in enclosures (Singaravelan et al., 2006). The latter authors, however, found that $50 \mathrm{ppm}$ nicotine reduced larval survival, with the highest mortality in day 3 larvae: this is $5 x$ higher than the highest concentration in our experiments. Increasingly it appears that the association between nicotine and honeybee survival is complex. Recently, we have found (Archer et al., in press) that low temperatures and nicotine interacted to reduce survival in African honeybee workers fed low protein diets, but that nicotine exposure alone did not reduce survival. Under certain conditions nicotine can even improve survival (Köhler et al. 2012a), perhaps due to its antipathogenic effects (Zaidi et al., 2012). Although little is known of the effects of xenobiotics on solitary bees it appears that solitary bees may also show some resistance to toxin exposure. For example, the nectar alkaloid gelsemine had no effect on offspring performance of Osmia lignaria when provisions were supplemented with gelseminecontaining nectar (Elliott et al., 2008). Abbott et al. (2008) found little effect of imidacloprid on $O$. lignaria or clothianidin on Megachile rotundata when they injected these neonicotinoids into pollen provisions or fed the larvae with contaminated pollen.

To help clarify the effects of toxins on bee larvae it is vital that we adopt standardised methodological approaches. This is because the dose, time of first exposure and duration of exposure may all influence the response of bee larvae to pesticides (Davis et al., 1988; Davis, 
1989). Chronic feeding of the toxin, as in our study, ensures accurate measurement of doses of the tested substance, whereas with a single feeding the volume ingested is unknown, because bees are always provided with a surplus of food (Aupinel et al., 2005). The in vitro larval rearing technique has been standardised for assessing effects of pesticides on honeybee brood; acute effects (24/48 h) are investigated by including the toxin in the diet on day 4 of larval development (second instar), and chronic effects by feeding the toxin from day 1 to day 6 (Aupinel et al., 2007; Zhu et al. 2014). Interestingly, Zhu et al. (2014) recorded the greatest mortality after four days of chronic feeding of pesticides to honeybee larvae; this toxicity is likely to be undetected in a conventional assay of acute effects.

We predicted that, even in the absence of effects on survival, nicotine might reduce larval growth and development, either because it reduces nutrient assimilation efficiency or because the energetic demands of detoxification drive trade-offs between investment in detoxification and growth. In keeping with this, dietary nicotine has negative effects on the development and digestive physiology of caterpillars, but researchers have tended to use higher concentrations of nicotine in artificial diets than those in our study. Studies on the tobacco hornworm Manduca sexta have used $0.1 \%$ or $0.5 \%$ wet weight, based on the normal range found in tobacco (Bentz and Barbosa, 1990; Harvey et al., 2007). An even higher concentration of $0.5 \%$ dry mass in diets of Spodoptera eridania had adverse effects on growth efficiency, and elevated respiration rates suggested a metabolic cost to detoxification of nicotine (Cresswell et al., 1992). However, the moderate doses of nicotine used in our study had no effect on lipid or protein reserves in bee larvae, indicating that they can tolerate toxin exposure without incurring substantial metabolic costs. Similarly, consumption of gelsemine by bumblebees had no effect on oocyte development as an indicator of protein utilization or on haemolymph carbohydrate concentrations, used as a proxy for the energetic cost of ingesting gelsemine (Manson and Thomson, 2009).

There are few data available on the body composition of honeybee larvae. Hrassnigg and Crailsheim (2005) reviewed differences in the physiology of drones and workers, and provided tables summarising the content of water, glycogen, lipids and protein for different life stages. Many of the cited references are very old. We measured protein averaging $23.7 \%$ dry mass, similar to the approximately $20 \%$ dry mass recorded by Hepburn et al. (1979) for prepupae of A. m. scutellata. These authors used the method of Lowry et al. (1951) which, like the Bradford method, is a colorimetric assay that measures the concentration of protein in 
solution based on a protein-dependant colour change (due to a dye complexing with proteins). In contrast, use of total nitrogen (determined by the Kjeldahl method) as an indicator of body protein gave a much higher value of $40 \%$ dry mass (Melampy et al., 1940): this includes other sources of nitrogen such as chitin and uric acid (although the latter should be minimal after defaecation). This lack of data means it is not clear how energy metabolism and storage are affected by exposure to pesticides. However, Derecka et al. (2013) found changes in lipid metabolism in honeybee larvae when hives were treated with low doses of imidacloprid. The stress resistance of bee larvae may be influenced by diet composition. For example, higher protein may benefit insects that need to upregulate their P450 enzymes and other detoxification pathways. In adult honeybees, Wahl and Ulm (1983) showed that the quality of pollens fed to young bees affected their subsequent response to pesticides, and Alaux et al. (2010b) found effects of pollen diets on immunocompetence. The resistance of laboratoryreared larvae to fungal parasites in the genus Aspergillus is enhanced by supplementing the diet with pollen if the royal jelly component of the larval diets is reduced (Foley et al., 2012). It is possible that our larvae may have shown stronger effects of nicotine if they were reared on a less than optimal diet - as we found with adult bees (Archer et al., in press). There is also a need to look at nicotine in combination with other stresses: the study by Köhler et al. (2012b) reported a decrease in worker survival when workers were exposed to the stress of dietary nicotine in combination with lipopolysaccharide (LPS) injection.

At the metabolic level, resistance mechanisms of insects to both plant toxins and synthetic insecticides involve the induction of detoxification enzymes such as cytochrome P450s, which transform xenobiotics into less toxic and more soluble compounds that can be excreted (Després et al., 2007). The lack of effect of nicotine on honeybee larvae may be due to good detoxification abilities (du Rand et al., unpublished data). Compared to other insect genomes, the honeybee genome encompasses far fewer xenobiotic-metabolising P450 genes (Claudianos et al., 2006). However, an expansion is observed in the CYP6AS subfamily (Mao et al. 2009) and a similar expansion in the CYP6 family in lepidopteran genomes is related to the xenobiotic detoxification ability of these insects (Li et al., 2003). The dominance and redundancy of the CYP6AS family in the honeybee genome may in part be responsible for the ability of bees to detoxify both natural (Mao et al., 2009) and synthetic (Mao et al., 2011; Suchail et al., 2003) xenobiotics present in their diet. An alternative - but not mutually exclusive - explanation for the resistance to pesticides suggested by our results could be the higher genetic variability of African honeybee populations. Although all major 
stressors are present, this may have resulted in selection for more resistant honeybees (Dietemann et al 2009). This could be tested by experiments comparing the response to xenobiotics of both larval and adult stages of different honeybee subspecies.

\section{Acknowledgments}

This work was funded jointly by a grant from the BBSRC, NERC, the Wellcome Trust, Defra, and the Scottish Government under the Insect Pollinators Initiative (BB/I000968/1). We also acknowledge the support of the National Research Foundation of South Africa and the University of Pretoria. Kendall Crous is thanked for beekeeping and help with analyses.

\section{References}

Abbott, V.A., Nadeau, J.L., Higo, H.A., Winston, M.L., 2008. Lethal and sublethal effects of imidacloprid on Osmia lignaria and clothianidin on Megachile rotundata (Hymenoptera: Megachilidae). Journal of Economic Entomology 101, 784-796.

Adler, L.S., Seifert, M.G., Wink, M., Morse, G.E., 2012. Reliance on pollinators predicts defensive chemistry across tobacco species. Ecology Letters 15, 1140-1148.

Alaux, C., Brunut, J.-L., Dussaubat, C., Mondet, F., Tchamitchan, S., Cousin, M., Brillard, J., Baldy, A., Belzunces, L.P., le Conte, Y., 2010a. Interactions between Nosema microspores and a neonicotinoid weaken honeybees (Apis mellifera). Environmental Microbiology 12, 774-782.

Alaux, C., Ducloz, F., Crauser, D., Le Conte, Y., 2010b. Diet effects on honeybee immunocompetence. Biology Letters 6, 562-565.

Archer, C.R., Pirk, C.W.W., Wright, G.A., Nicolson, S.W., 2013. Nutrition affects survival in African honeybees (Apis mellifera scutellata) exposed to interacting stressors. Functional Ecology doi:http://dx.doi.org/10.1111/1365-2435.12226.

Aupinel, P., Fortini, D., Dufour, H., Tasei, J.-N., Michaud, B., Odoux, J.-F., Pham-Delègue, M.-H., 2005. Improvement of artificial feeding in a standard in vitro method for rearing Apis mellifera larvae. Bulletin of Insectology 58, 107-111. 
Aupinel, P., Fortini, D., Michaud, B., Marolleau, F., Tasei, J.-N., Odoux, J.-F., 2007.

Toxicity of dimethoate and fenoxycarb to honey bee brood (Apis mellifera), using a new in vitro standardized feeding method. Pest Management Science 63, 1090-1094.

Bentz, J.-A., Barbosa, P., 1990. Effect of dietary nicotine (0.1\%) and parasitism by Cotesia congregata on the growth and food consumption and utilization of the tobacco hornworm, Manduca sexta. Entomologia Experimentalis et Applicata 57, 1-8.

Blacquière, T., Smagghe, G., van Gestel, C.A.M., Mommaerts, V., 2012. Neonicotinoids in bees: a review on concentrations, side-effects and risk assessment. Ecotoxicology 21, 973-992.

Bradford, M.M., 1976. A rapid and sensitive method for the quantitation of microgram quantities of protein utilizing the principle of protein-dye binding. Analytical Biochemistry 72, 248-254.

Casanova, H., Ortiz, C., Peláez, C., Vallejo, A., Moreno, M.E., Acevedo, M., 2002. Insecticide formulations based on nicotine oleate stabilized by sodium caseinate. Journal of Agricultural and Food Chemistry 50, 6389-6394.

Chauzat, M.-P., Faucon, J.-P., 2007. Pesticide residues in the beeswax samples collected from honey bee colonies (Apis mellifera L.) in France. Pest Management Science 63, 1100-1106.

Chauzat, M.-P., Faucon, J.-P., Martel, A.-C., Lachaize, J., Cougoule, N., Aubert, M., 2006. A survey of pesticide residues in pollen loads collected by honey bees in France. Journal of Economic Entomology 99, 253-262.

Claudianos, C., Ranson, H., Johnson, R.M., Biswas, S., Schuler, M.A., Berenbaum, M.R., Feyereisen, R., Oakeshott, J.G., 2006. A deficit of detoxification enzymes: pesticide sensitivity and environmental response in the honeybee. Insect Molecular Biology 15, 615-636.

Crailsheim, K., Brodschneider, R., Aupinel, P., Behrens, D., Genersch, E., Vollmann, J., Riessberger-Gallé, U., 2013. Standard methods for artificial rearing of Apis mellifera larvae. Journal of Apicultural Research 52, 1-15.

Cresswell, J.E., Merritt, S.Z., Martin, M.M., 1992. The effect of dietary nicotine on the allocation of assimilated food to energy metabolism and growth in fourth-instar larvae of the southern armyworm, Spodoptera eridania (Lepidoptera: Noctuidae). Oecologia $89,449-453$.

Davis, A.R., 1989. The study of insecticide poisoning of honeybee brood. Bee World 70, 163-174. 
Davis, A.R., Solomon, K.R., Shuel, R.W., 1988. Laboratory studies of honeybee larval growth and development as affected by systemic insecticides at adult-sublethal levels. Journal of Apicultural Research 27, 146-161.

Decourtye, A., Devilliers, J., 2009. Ecotoxicity of neonicotinoid insecticides to bees, in: Thany, S.H. (Ed.), Insect Nicotinic Acetylcholine Receptors. Springer, New York, pp. $85-95$.

Derecka, K., Blythe, M.J., Mala, S., Genereux, D.P., Guffanti, A., Pavan, P., Moles, A., Snart, C., Ryder, T., Ortori, C.A., Barrett, D.A., Schuster, E., Stoger, R., 2013. Transient exposure to low levels of insecticide affects metabolic networks of honeybee larvae. PLoS ONE 8, e68191.

Després, L., David, J.-P., Gallet, C., 2007. The evolutionary ecology of insect resistance to plant chemicals. Trends in Ecology and Evolution 22, 298-307.

Detzel, A., Wink, M., 1993. Attraction, deterrence or intoxication of bees (Apis mellifera) by plant allelochemicals. Chemoecology 4, 8-18.

Dietemann, V., Pirk, C. W. W., Crewe, R. M., 2009. Is there a need for conservation of honeybees in Africa? Apidologie 40, 285-295.

Elliott, S.E., Irwin, R.E., Adler, L.S., Williams, N.M., 2008. The nectar alkaloid, gelsemine, does not affect offspring performance of a native solitary bee, Osmia lignaria (Megachilidae). Ecological Entomology 33, 298-304.

Foley, K., Fazio, G., Jensen, A.B., Hughes, W.O.H., 2012. Nutritional limitation and resistance to opportunistic Aspergillus parasites in honey bee larvae. Journal of Invertebrate Pathology 111, 68-73.

Gill, R.J., Ramos-Rodriguez, O., Raine, N.E., 2012. Combined pesticide exposure severely affects individual- and colony-level traits in bees. Nature 491, 105-108.

Harvey, J.A., van Dam, N.M., Witjes, L.M., Soler, R., Gols, R., 2007. Effects of dietary nicotine on the development of an insect herbivore, its parasitoid and secondary hyperparasitoid over four tropic levels. Ecological Entomology 32, 15-23.

Hendriksma, H.P., Härtel, S., Steffan-Dewenter, I., 2011. Honey bee risk assessment: new approaches for in vitro larvae rearing and data analyses. Methods in Ecology and Evolution 2, 509-517.

Hepburn, H.R., Cantrill, R.C., Thompson, P.R., Kennedi, E., 1979. Metabolism of carbohydrate, lipid and protein during development of sealed worker brood of the African honeybee. Journal of Apicultural Research 18, 30-35. 
Hrassnigg, N., Crailsheim, K., 2005. Differences in drone and worker physiology in honeybees (Apis mellifera). Apidologie 36, 255-277.

Johnson, R.M., Mao, W., Pollock, H.S., Niu, G., Schuler, M.A., Berenbaum, M.R., 2012. Ecologically appropriate xenobiotics induce cytochrome P450s in Apis mellifera. PLoS ONE 7, e31051.

Kanga, L.H.B., Somorin, A.B., 2011. Susceptibility of the small hive beetle, Aethina tumida (Coleoptera: Nitidulidae), to insecticides and insect growth regulators. Apidologie 43, 95-102.

Köhler, A., Pirk, C.W.W., Nicolson, S.W., 2012a. Honeybees and nectar nicotine: deterrence and reduced survival versus potential health benefits. Journal of Insect Physiology 58, 286-292.

Köhler, A., Pirk, C.W.W., Nicolson, S.W., 2012b. Simultaneous stressors: interactive effects of an immune challenge and dietary toxin can be detrimental to honeybees. Journal of Insect Physiology 58, 918-923.

Li, W., Schuler, M.A., Berenbaum, M.R., 2003. Diversification of furanocoumarinmetabolizing cytochrome P450 monooxygenases in two papilionids: specificity and substrate encounter rate. Proceedings of the National Academy of Sciences, USA 100, 14593-14598.

Lowry, O.H., Rosebrough, N.J., Farr, A.L., Randall, R.N., 1951. Protein measurement with the Folin phenol reagent. Journal of Biological Chemistry 193, 265-275.

Manson, J.S., Thomson, J.D., 2009. Post-ingestive effects of nectar alkaloids depend on dominance status of bumblebees. Ecological Entomology 34, 421-426.

Mao, W., Rupasinghe, S.G., Johnson, R.M., Zangerl, A.R., Schuler, M.A., Berenbaum, M.R., 2009. Quercetin-metabolizing CYP6AS enzymes of the pollinator Apis mellifera (Hymenoptera: Apidae). Comparative Biochemistry and Physiology, Part B 154, 427 434.

Mao, W., Schuler, M.A, Berenbaum, M.R., 2011. CYP9Q-mediated detoxification of acaricides in the honey bee (Apis mellifera). Proceedings of the National Academy of Sciences, USA 108, 12657-12662.

Matsuda, K., Buckingham, S.D., Kleier, D., Rauh, J.J., Grauso, M., Sattelle, D.B., 2001. Neonicotinoids: insecticides acting on insect nicotinic acetylcholine receptors. Trends in Pharmacological Sciences 22, 573-580. 
Melampy, R.M., Willis, E.R., McGregor, S.E., 1940. Biochemical aspects of the differentiation of the female honeybee (Apis mellifera L.). Physiological Zoology 13, 283-293.

Mullin, C.A., Frazier, M., Frazier, J.L., Ashcraft, S., Simonds, R., vanEngelsdorp, D., Pettis, J.S., 2010. High levels of miticides and agrochemicals in North American apiaries: implications for honey bee health. PLoS ONE 5, e9754.

Pettis, J.S., vanEngelsdorp, D., Johnson, R., Dively, G., 2012. Pesticide exposure in honey bees results in increased levels of the gut pathogen Nosema. Naturwissenschaften 99, 153-158.

Pettis, J.S., Lichtenberg, E.M., Andree, M., Stitzinger, J., Rose, R., vanEngelsdorp, D., 2013. Crop pollination exposes honey bees to pesticides which alters their susceptibility to the gut pathogen Nosema ceranae. PLoS ONE 8, e70182.

Pirk, C.W.W., de Miranda, J.R., Kramer, M., Murray, T.E., Nazzi, F., Shutler, D., van der Steen, J.J.M., and van Dooremalen, C., 2013. Statistical guidelines for Apis mellifera research. Journal of Apicultural Resarch 52: doi:http://dx.doi.org/10.3896/IBRA.1.52.4.13.

Potts, S.G., Biesmeijer, J.C., Kremen, C., Neumann, P., Schweiger, O., Kunin, W.E., 2010. Global pollinator declines: trends, impacts and drivers. Trends in Ecology and Evolution 25, 345-353.

Singaravelan, N., Inbar, M., Ne'eman, G., Distl, M., Wink, M., Izhaki, I., 2006. The effects of nectar-nicotine on colony fitness of caged honeybees. Journal of Chemical Ecology $32,49-58$.

Suchail, S., Guez, D., Belzunces, L.P., 2000. Characteristics of imidacloprid toxicity in two Apis mellifera subspecies. Environmental Toxicology and Chemistry 19, 1901-1905.

Suchail, S., Debrauwer, L., Belzunces, L.P., 2003. Metabolism of imidacloprid in Apis mellifera. Pest Management Science 60, 291-296.

Vanbergen, A.J., Baude, M., Biesmeijer, J.C., Britton, N.F., Brown, M.J.F., Brown, M., Bryden, J., Budge, G.E., Bull, J.C., Carvell, C.C., Challinor, A.J., Connolly, C.N., Evans, D.J., Feil, E.J., Garratt, M.P., Greco, M.K., Heard, M.S., Jansen, V.A.A., Keeling, M.J., Kunin, W.E., Marris, G.C., Memmott, J., Murray, J.T., Nicolson, S.W., Osborne, J.L., Paxton, R.J., Pirk, C.W.W., Polce, C., Potts, S.G., Priest, N.K., Raine, N.E., Rushton, S.P., Ryabov, E.V., Shafir, S. Shirley, M.D.F., Simpson, S.J., Smart, S.M., Stevenson, P.C., Stone, G.N., Termansen, M., Wright, G.A., 2013. Threats to an 
ecosystem service: multifactorial pressures on insect pollinators. Frontiers in Ecology and the Environment 11:251-259.

VanEngelsdorp, D., Meixner, M.D., 2010. A historical review of managed honey bee populations in Europe and the United States and the factors that may affect them. Journal of Invertebrate Pathology 103, S80-S95.

Vidau, C., Diogon, M., Aufauvre, J., Fontbonne, R., Viguès, B., Brunet, J.-L., Texier, C., Biron, D.G., Blot, N., El Alaoui, H., Belzunces, L.P., Delbac, F., 2011. Exposure to sublethal doses of fipronil and thiacloprid highly increases mortality of honeybees previously infected by Nosema ceranae. PLoS ONE 6, e21550.

Wahl, O., Ulm, K., 1983. Influence of pollen feeding and physiological condition on pesticide sensitivity of the honey bee Apis mellifera carnica. Oecologia 59, 106-128.

Williamson, S.M., Wright, G.A., 2013. Exposure to multiple cholinergic pesticides impairs olfactory learning and memory in honeybees. Journal of Experimental Biology 216, 1799-1807.

Wu, J.Y., Anelli, C.M., Sheppard, W.S., 2011. Sub-lethal effects of pesticide residues in brood comb on worker honey bee (Apis mellifera) development and longevity. PLoS ONE 6, e14720.

Yang, E.-C., Chang, H.-C., Wu, W.-Y., Chen, Y.-W., 2012. Impaired olfactory associative behavior of honeybee workers due to contamination of imidacloprid in the larval stage. PLoS ONE 7, e49472.

Zaidi, M.I., Wattoo, F.H., Wattoo, M.H., Tirmizi, S.A., Salman, S. 2012. Antibacterial activities of nicotine and its zinc complex. African Journal of Microbiology Research 6, 5134-5137.

Zhu, W., Schmehl, D.R., Mullin, C.A., Frazier, J.L., 2014. Four common pesticides, their mixtures and a formulation solvent in the hive environment have high oral toxicity to honey bee larvae. PLoS ONE 9, e77547. 